\title{
Comparative Study of the Effect of ACE-Inhibitors and Other Antihypertensive Agents on Proteinuria in Diabetic Patients
}

\author{
Lorenz Böhlen, Maximilian de Courten, and Peter Weidmann
}

Several studies during the past 15 years have shown that antihypertensive therapy with different types of drugs can reduce microalbuminuria or clinical proteinuria and retard the progression toward end-stage renal failure. However, some authors reported disparate renal protective effects of different antihypertensive drugs in diabetic animals and humans. In an attempt to resolve the controversy surrounding this possibility, previously we reported a meta-analysis of published studies in diabetics with microalbuminuria or overt proteinuria treated with conventional agents, angiotensin-converting enzyme (ACE) inhibitors, or calcium antagonists $\left(\mathrm{Ca}^{2+}\right.$ antagonists). Here we present an updated meta-analysis of published studies in diabetics with microalbuminuria or clinical proteinuria (UProt), treated during $\geq 4$ weeks with ACE inhibitors, $\mathrm{Ca}^{2+}$ antagonists, or conventional therapy (diuretic and/or $\beta$-blocker). Despite similar blood pressure (BP) reductions, UProt tended to decrease more on ACE inhibitors (on average $-45 \%$ ) than on conventional therapy (on average $-23 \%$ ) or $\mathrm{Ca}^{2+}$ antagonists other than nifedipine (on average $-35 \%$ ); in contrast, UProt tended to increase slightly on nifedipine (on average $5 \%$, $P<.05)$. On the basis of multiple regression analysis, ACE inhibitor-induced UProt changes correlated with $B P$ changes $(r=0.77, P<.00001)$, averaged $-28 \%$ at zero $B P$ change, and varied $1.5 \%$ for each percent BP change. On conventional therapy, UProt and BP changes also correlated $(r=0.62, P$ $<$.005), but UProt began to decrease only after a BP reduction of $>5 \%$ and the slope was steeper
(4\% UProt change per percent BP change) than on ACE inhibitors. On $\mathrm{Ca}^{2+}$ antagonists other than nifedipine, UProt was unchanged at zero BP change, and the regression line for the relationship between changes in UProt $(r=0.55, P<.05)$ was in an intermediate position between ACE inhibitors and conventional treatment. Seventy reports also contained data on glomerular filtration rate (GFR). On ACE inhibitors, GFR was on average unchanged, but tended to increase slighty with progressive $B P$ reduction $(r=-0.55, P<.0001)$. On conventional therapy or $\mathrm{Ca}^{2+}$. antagonists, variations in GFR were unrelated to changes in BP.

As ACE inhibitors exert a specific antiproteinuric effect even without a change in systemic BP, they are superior to other agents in treating microalbuminuria or overt proteinuria in initially normotensive or mildly hypertensive diabetic patients. On the other hand, when systemic BP can be lowered by $20 \%$, as it is desirable in severely hypertensive patients, ACE inhibitors, conventional therapy, and several $\mathrm{Ca}^{2+}$ antagonists all have a distinct antiproteinuric action. In contrast, as the example of nifedipine illustrates, drug-specific intrarenal effects may antagonize a BP-dependent antiproteinuric action and even counteract the effect of lowering systemic pressure. It is of note that ACE inhibitors may, in addition to their antiproteinuric effect, exert a drug-specific beneficial influence on GFR. Am J Hypertens 1994;7:84S-92S KEY WORDS: Microalbuminuria, overt proteinuria, angiotensin-converting enzyme inhibitors, calcium antagonists, glomerular filtration rate.
From the Medizinische Universitäts-Poliklinik, Berne, Switzerland. Address correspondence to Peter Weidmann, MD, Professor of
Medicine, Medizinische Universitäts-Poliklinik Freiburgstrasse 6, 3010 Berne, Switzerland. 
T The incidence and prevalence of renal failure secondary to diabetes mellitus has increased steadily during the past decade in the United States $^{1}$; therefore, diabetes is now the leading cause of end-stage renal disease. ${ }^{2}$ Microalbuminuria $(30$ to $300 \mathrm{mg} / 24 \mathrm{~h}$ ) predicts overt nephropathy (proteinuria $>300 \mathrm{mg} / 24 \mathrm{~h}$ ) and chronic renal failure in diabetic individuals. ${ }^{3}$ It has also a powerful association with macrovascular disease, which is unexplained by simultaneous existing cardiovascular risk factors. ${ }^{4}$

Among the $35 \%$ of patients with insulin-dependent diabetes mellitus (IDDM) who will develop nephropathy, persistent microalbuminuria ("incipient nephropathy") appears 5 to 10 years after the onset of diabetes. It usually progresses to the stages of overt nephropathy and later on to end-stage renal failure. ${ }^{5,6}$ Hypertension contributes to the progression of diabetic nephropathy in IDDM. ${ }^{7}$ Blood pressure (BP) is usually normal in the absence of nephropathy, tends to rise before or concomitantly with the onset of incipient nephropathy, and increases further when renal damage progresses to the stages of clinical nephropathy and renal failure. ${ }^{5,8,9}$ In patients with non-insulin-dependent diabetes mellitus (NIDDM), the temporal relationship between the onset of hypertension and nephropathy, respectively, is more variable; hypertension most often precedes and sometimes follows diabetes. On the one hand, progression of nephropathy aggravates hypertension, ${ }^{10,11}$ but on the other hand once nephropathy is present, a high BP may also promote and accelerate the development of renal failure. ${ }^{10}$ Compared with the general population, relative mortality from cardiovascular disease is increased about fivefold in diabetics with hypertension ${ }^{12,13}$ and about 35 -fold in diabetics with clinical nephropathy. ${ }^{7,14}$

Attempts at slowing progression of overt diabetic nephropathy have included dietary modifications and antihypertensive therapy. Severe restriction of protein intake may slightly retard progression to renal failure, ${ }^{15}$ but the feasibility and acceptability of this dietary modification are even more problematic in diabetic than in nondiabetic patients. Several studies during the past 15 years have shown that antihypertensive therapy with different types of drugs can reduce microalbuminuria or clinical proteinuria and retard the progression toward end-stage renal failure. . $^{5,16-20}$ Reduction of proteinuria and attenuation of the loss of glomerular filtration rate (GFR) were observed initially with conventional antihypertensive therapy, including diuretics and $\beta$-blockers, ${ }^{16,17}$ the exception being monotherapy with diuretics, which was suspected to accelerate diabetic nephropathy. ${ }^{21}$

Concerning the choice of antihypertensive agents, a new argument was introduced by some studies suggesting disparate renal protective effects of different antihypertensive drugs in diabetic animals ${ }^{19,22-25}$ and humans. ${ }^{26}$ In an attempt to resolve the controversy around this possibility, we reported a meta-analysis of published studies in diabetics with microalbuminuria or overt proteinuria treated with conventional agents, angiotensin-converting enzyme (ACE) inhibitors, or $\mathrm{Ca}^{2+}$ antagonists. ${ }^{27,28}$ Here, we present an updated meta-analysis of treatment-effects concerning not only proteinuria but also GFR.

\section{METHODS}

Studies and Experimental Groups The literature was screened for clinical trials using any antihypertensive agents in diabetic patients. The search was performed using MEDLINE and publications and abstracts of recent major congresses. Studies fulfilling the following criteria were included in our previous report ${ }^{28}$ and the present analysis: 1) diabetic patients receiving conventional antihypertensive drugs (diuretics and/or $\beta$-blockers and sometimes also hydralazine-type vasodilators) or a monotherapy with ACE inhibitors or $\mathrm{Ca}^{2+}$ antagonists, 2) measurements of albuminuria or total proteinuria and BP before and after therapy lasting $\geq 4$ weeks, and 3) pretreatment albuminuria (proteinuria) $\geq 30 \mathrm{mg} /$ day. The following exclusion criteria were applied: 1) combination therapy if patients were on ACE inhibitors or $\mathrm{Ca}^{2+}$ antagonists, 2) normal albumin excretion ( $<30 \mathrm{mg} /$ day) at the beginning of the study, 3) studies lasting $<4$ weeks, and 4) repetitive reports of partly similar patient groups (from such series, only the most complete report with the largest population was included).

Because the literature so far contains only a few double-blinded studies with a parallel placebo control group, this analysis could not be done without inclusion of studies that were uncontrolled but fulfilled all of the above mentioned criteria. The following data were extracted: information on the type and known duration of diabetes; number, mean age, and gender of patients; duration of active drug treatment; and pre- and posttreatment mean values for urinary albumin or total protein excretion, BP, and, if reported, GFR estimated by inulin, ${ }^{125} \mathrm{I}$-iothalamate, ${ }^{51} \mathrm{Cr}$ EDTA, ${ }^{99} \mathrm{Tc}$-DTPA, or $24 \mathrm{~h}$-creatinine clearance.

Statistical Analysis Study end-points were mean arterial BP $(\mathrm{mm} \mathrm{Hg})$, GFR $(\mathrm{mL} / \mathrm{min})$, and urine protein excretion defined as either albumin or total protein excretion $(\mu \mathrm{g} / \mathrm{min})$. Each end-point consisted of two values, one at baseline and one after treatment. The relative change of the mean (expressed as percentage) between these two timepoints was used for analysis. In studies with more than one measurement after $\geq 4$ weeks of treatment duration, the mean value was used.

Statistical analyses were performed using the software package of the SAS Institute (Cary, NC).$^{29}$ Ef- 
fects of antihypertensive therapy on urinary albumin or protein excretion, mean BP and GFR were calculated separately for the different classes of agents. Treatment effects were weighted by the number of patients in each report in relation to the total number of patients and number of reports, and mean values and $95 \%$ confidence intervals (CI) were calculated. Differences between the drug-specific classes were tested by analysis of variance and were considered significant at $P<.05$ (two-tailed). Multiple regression analysis was applied to determine the influence of different independent explanatory variables on study end points. Type of medication, initial mean BP, initial urinary albumin or total protein excretion, type of diabetes, duration of the study, and number of patients investigated were considered as independent variables. Forward stepwise regression analysis was then performed for each treatment group to identify which of the independent variables could be explanatory for renal effects. Linear regression analysis was carried out using change in mean BP, initial mean BP, or initial level of albumin or total protein excretion as independent variables and change in urinary albumin or total protein excretion and change in GFR, as dependent variables. ANOVA was used to compare the differences between the agent-specific groups. F-test for equal variances in groups with different sample sizes did not reveal any violation of the ANOVA assumptions. The statistical difference of the final regression lines were calculated using a model as described by Kleinbaum et al. ${ }^{30}$

\section{RESULTS}

Study Characteristics From 260 publications identified by the literature search 93 fulfilled the inclusion criteria and contained 115 treatment groups. Of these, 68 treatment groups were allocated to the ACE inhibitor category $28,31-62,27^{28,38,45,53,57,61,63}$ to the $\mathrm{Ca}^{2+}$ antagonist category, and $21^{28,42,58,61,64-69}$ to the conventional (diuretic and/or $\beta$-blocker) treatment category (Table 1).

The analysis included a total of 1610 patients with a mean age of $46 \pm 11$ years (mean \pm SEM) in all reports. The mean proportion of men in all reports was $62 \pm 23 \%$. The reported type of diabetes was $39 \%$ for type I, $37 \%$ type II, in $11 \%$ a mixture of both types, and in $13 \%$ of the reports no indication was given. Age, gender, type of diabetes, and mean duration of therapy did not differ significantly between the treatment groups.

Urine Albumin or Total Protein Excretion Albuminuria or total proteinuria tended to decrease on average more on ACE inhibitors than on conventional therapy or all $\mathrm{Ca}^{2+}$ antagonists together, but the difference did not reach statistical significance. Moreover, albuminuria or total proteinuria tended to increase on nifedipine, despite similar average BP reductions (Table 1$)$. This differs significantly $(P<.05)$ from changes on conventional therapy, ACE inhibitors, or $\mathrm{Ca}^{2+}$ antagonists other than nifedipine.

$\mathrm{ACE}$ inhibitor-induced changes in albuminuria or proteinuria correlated significantly with decreases in $\mathrm{BP}(\mathrm{r}=0.77, P<.00001$; Figure 1). The decrease in albuminuria or proteinuria averaged $-28 \%$ at zero $\mathrm{BP}$ change, and varied $1.5 \%$ for each percent BP change. The slope and intercept describing reduction of albuminuria as a function of the decrement in $\mathrm{BP}$ differs between ACE inhibitors and the other antihypertensive therapies $(P<.05)$. The effects of structurally different ACE inhibitors were similar (data not shown). The duration of therapy with ACE inhibitors did not affect the magnitude of change in proteinuria.

On therapy with conventional antihypertensive agents, changes in albuminuria-proteinuria and BP were also correlated $(\mathrm{r}=0.61, P<.005$, slope 4.0 , $y$-intercept 15.9; Figure 2). However, albumin or total protein excretion started to decrease only at a BP reduction of $>5 \%$, and the slope was steeper (4\% change in albuminuria-proteinuria per percent $\mathrm{BP}$ change) than on ACE inhibitors. The regression line differed from the $\mathrm{ACE}$ inhibitors regression line but not in comparison with the regression line on treatment with $\mathrm{Ca}^{2+}$ antagonists other than nifedipine.

TABLE 1. ANTIPROTEINURIC ACTION OF ANTIHYPERTENSIVE DRUGS IN DIABETICS: META-ANALYSIS

\begin{tabular}{|c|c|c|c|c|c|}
\hline \multirow{3}{*}{$\begin{array}{l}\text { Type of } \\
\text { Therapy }\end{array}$} & \multirow{2}{*}{\multicolumn{2}{|c|}{$\mathbf{N}$}} & \multirow{3}{*}{$\begin{array}{c}\text { Mean Study } \\
\text { Duration (mo) }\end{array}$} & \multicolumn{2}{|c|}{ Average Changes (\%) } \\
\hline & & & & \multirow{2}{*}{$\begin{array}{c}\text { Mean } \\
\text { Systemic BP }\end{array}$} & \multirow{2}{*}{$\begin{array}{l}\text { Urinary Albumin } \\
\text { or Protein }\end{array}$} \\
\hline & Reports & Subjects & & & \\
\hline Diuretics and/or $\beta$-blockers & 21 & 258 & $15.5(9 / 22)$ & $-10(-12 /-8)$ & $-23(-35 /-11)$ \\
\hline ACE inhibitors & 68 & 1061 & $8.2(6 / 11)$ & $-12(-19 /-5)$ & $-45(-64 /-25)$ \\
\hline \multicolumn{6}{|l|}{$\mathrm{Ca}^{2+}$ antagonists } \\
\hline all & 27 & 398 & $5.4(3 / 7)$ & $-12(-15 /-10)$ & $-17(-33 /-2)$ \\
\hline Nifedipine & 12 & 166 & $5.9(3 / 9)$ & $-13(-17 /-9)$ & $+5(-21 /+31)$ \\
\hline all except nifedipine & 15 & 232 & $5.0(2 / 8)$ & $-11(-14 /-7)$ & $-35(-47 /-24)$ \\
\hline
\end{tabular}

Mean $(95 \%$ confidence interval).

$* \mathrm{P}<.05$. 


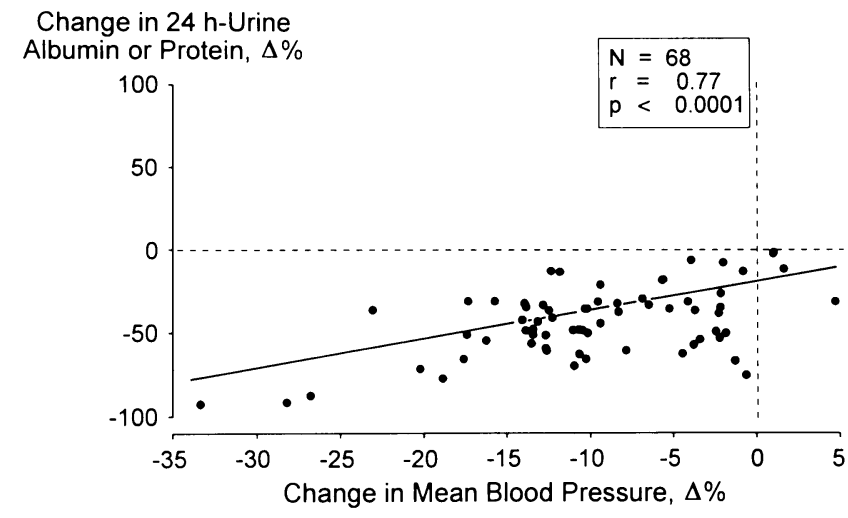

FIGURE 1. Percentage changes in albuminuria-proteinuria as related to blood pressure changes in diabetics on angiotensinconverting enzyme inhibitors.

Although the distribution of data points did not differ obviously between reports using diuretic monotherapy, $\beta$-blocker monotherapy, or their combination, differences between their monotherapy or combination are not excluded as the limited number of reports precludes a separate analysis.

In the treatment group including all $\mathrm{Ca}^{2+}$ antagonists, changes in albuminuria or proteinuria were unrelated to BP changes (Figure 3). Further stratification of this group into two subgroups treated with either nifedipine or $\mathrm{Ca}^{2+}$ antagonists other than nifedipine (including verapamil, diltiazem, and the dihydropyridines nicardipine, nitrendipine, and isradipine), revealed a significant relationship between change in $\mathrm{BP}$ and albumin or total protein excretion in the latter ( $\mathrm{r}=0.55, P<.05$, slope 2.6, y-intercept -7.9 ; Figure 3 ), but not in the nifedipine subgroup. In 4 of 13 studies $^{55,60,70,71}$ with nifedipine, proteinuria was reported to be increased despite of a decrease in BP. Choosing another subgroup assignment, namely

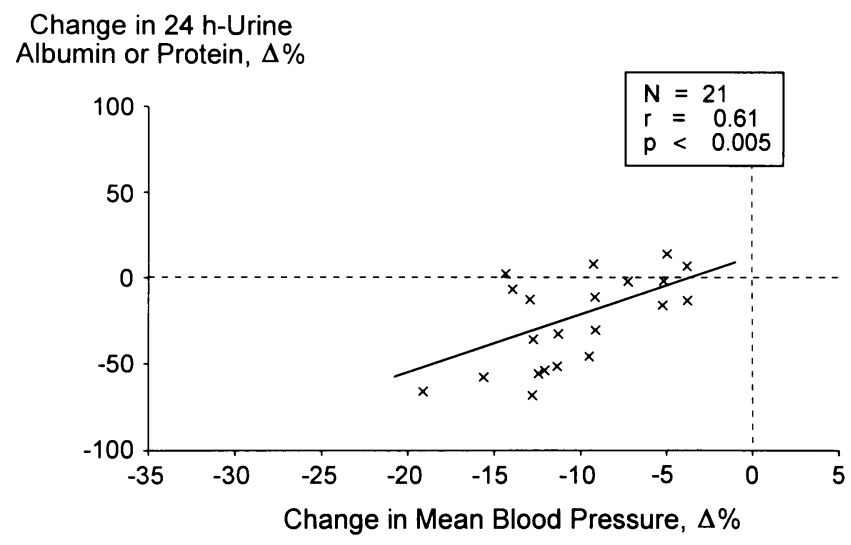

FIGURE 2. Percentage changes in albuminuria-proteinuria as related to blood pressure changes in diabetics on "conventional" drugs.

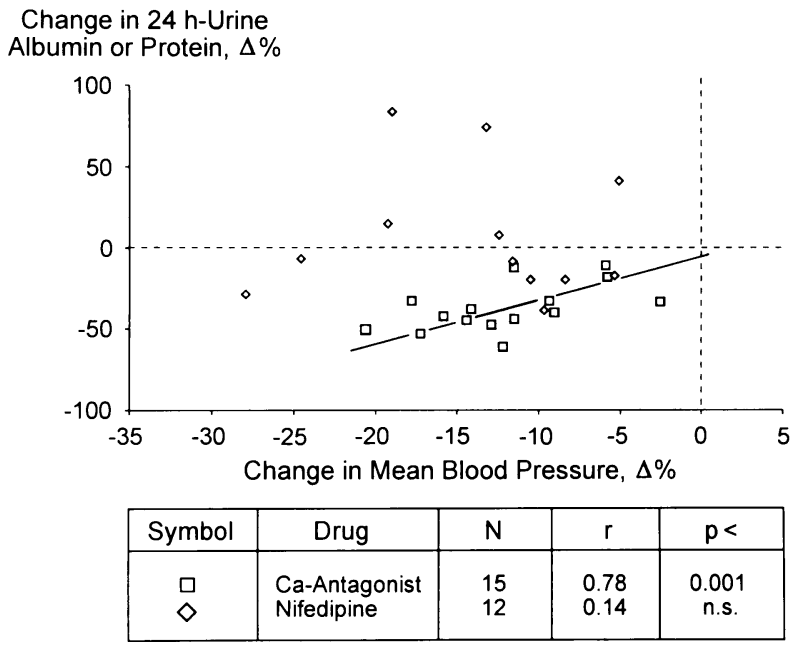

FIGURE 3. Percentage changes in albuminuria-proteinuria as related to blood pressure changes in diabetic on $\mathrm{Ca}^{2+}$ antagonists (Ca-Antagonist) and nifedipine.

$\mathrm{Ca}^{2+}$ antagonists of the dihydropirine type versus nondihydropyridines revealed no statistical relationship between the reduction in albuminuria and decrease in mean BP.

Glomerular Filtration Rate Seventy reports contained data on $\mathrm{GFR}^{20,21,28,32,36,38,39,41-43,46,49,51,52,54-56,63,67,69,70}$ (Table 2). The latter was measured by the clearances of inulin, ${ }^{99} \mathrm{Tc}-\mathrm{DTPA},{ }^{125} \mathrm{I}$-iothalamate, or ${ }^{51} \mathrm{Cr}$-EDTA in 53 studies and was estimated by the clearance of creatinine in 17 studies.

During the observation period, GFR on average was unchanged on ACE inhibitors and tended to decrease minimally on conventional therapy or all $\mathrm{Ca}^{2+}$-antagonists analyzed together. Although changes did not reach statistical significance, this tendency was associated with nifedipine treatment (Table 2).

ACE inhibitor-induced changes in GFR correlated inversely with changes in mean BP, therefore GFR tended to increase with progressive $\mathrm{BP}$ reduction (Figure 4). On $\mathrm{Ca}^{2+}$ antagonists or conventional therapy, variations in GFR were unrelated to changes in BP.

\section{DISCUSSION}

These findings demonstrate a predominance of drugspecific over systemic BP-dependent mechanisms in the antiproteinuric action of ACE inhibitors in diabetic patients. In contrast, as the example of nifedipine illustrates, drug-specific intrarenal effects may antagonize a BP-dependent antiproteinuric action and even counteract the effect of lowering systemic BP. 
TABLE 2. EFFECTS OF ANTIHYPERTENSIVE DRUGS ON GLOMERULAR FILTRATION IN DIABETICS: META-ANALYSIS

\begin{tabular}{|c|c|c|c|c|c|}
\hline \multirow{3}{*}{$\begin{array}{l}\text { Type of } \\
\text { Therapy }\end{array}$} & \multirow{2}{*}{\multicolumn{2}{|c|}{$\mathbf{N}$}} & \multirow{3}{*}{$\begin{array}{c}\text { Mean Study } \\
\text { Duration (mo) }\end{array}$} & \multicolumn{2}{|c|}{ Average Changes (\%) } \\
\hline & & & & \multirow{2}{*}{$\begin{array}{c}\text { Mean } \\
\text { Systemic BP }\end{array}$} & \multirow{2}{*}{$\begin{array}{c}\text { Glomerular } \\
\text { Filtration Rate* }\end{array}$} \\
\hline & Reports & Subjects & & & \\
\hline Diuretics and/or $\beta$-blockers & 16 & 190 & $16.4(8 / 25)$ & $-11(-13 /-8)$ & $-1.9(-10 /-1)$ \\
\hline ACE inhibitors & 38 & 604 & $6.8(5 / 9)$ & $-16(-28 /-4)$ & $-0.01(-6 /+6)$ \\
\hline \multicolumn{6}{|l|}{$\mathrm{Ca}^{2+}$ antagonists } \\
\hline All & 16 & 205 & $6.6(3 / 16)$ & $-14(-17 /-10)$ & $-2.2(-11 /+7)$ \\
\hline Nifedipine & 8 & 107 & $7.4(2 / 12)$ & $-14(-20 /-9)$ & $-9.9(-25 /+5)$ \\
\hline all except nifedipine & 8 & 98 & $5.8(1 / 11)$ & $-13(-17 /-8)$ & $+5.6(-4 /+15)$ \\
\hline
\end{tabular}

Mean $(95 \%$ confidence interval).

${ }^{* 51} \mathrm{Cr}$-EDTA, Inulin, ${ }^{125}$ I-iothalamate, ${ }^{99} \mathrm{Tc}$-DTPA or creatinine clearance.

With progressive lowering of $\mathrm{BP}$, the antialbuminuric effect increases less on ACE inhibitors than on conventional antihypertensive therapy or $\mathrm{Ca}^{2+}$ antagonists other than nifedipine. It is obvious from Figure 5 that a difference or no difference between ACE inhibitors and alternative antihypertensive treatments may occur depending on how markedly BP has been lowered. This explains some controversies in the literature.

This meta-analysis also reveals that with progressive $B P$ reduction GFR tended to increase on ACE inhibitors, but not on conventional antihypertensive therapy or $\mathrm{Ca}^{2+}$ antagonists. This complements the disparate renal profile of different antihypertensive agents in diabetics with incipient or overt nephropathy.

Renal effects of antihypertensive agents are medi-

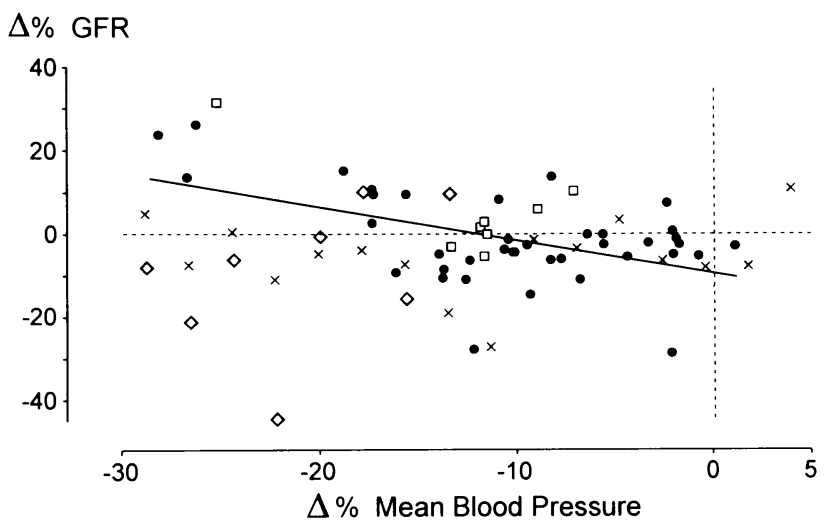

\begin{tabular}{|c|l|r|r|c|}
\hline Symbol & Drug & $\mathrm{N}$ & $\mathrm{r}$ & $\mathrm{p}<$ \\
\hline$\bullet$ & ACE Inhibitor & 39 & -0.55 & 0.0005 \\
$\times$ & Conventional & 16 & 0.12 & n.s. \\
$\square$ & Ca-Antagonist & 8 & 0.43 & n.s. \\
$\diamond$ & Nifedipine & 8 & 0.46 & n.s. \\
\hline
\end{tabular}

FIGURE 4. Percentage changes in glomerular filtration rate (GFR) as related to blood pressure changes in diabetics on antihypertensive drugs. ated, at least in part, by direct intrarenal actions. Intrarenal hemodynamics, tubular function, or mesangial cell metabolism may be modified.

ACE inhibitors block the generation of angiotensin II, a potent inducer of intrarenal vasoconstriction. Furthermore, ACE inhibitors increase levels of vasodilatory prostaglandins PGI2 and PGE2 through inhibition of kininase II, an enzyme identical to ACE. ${ }^{72}$ Therefore, these agents dilate both afferent and efferent arterioles and consequently reduce glomerular capillary pressure. Because they dilate preferentially efferent over afferent glomerular arterioles, ${ }^{73}$ a fall in systemic BP will cause a greater.decrease of glomerular capillary pressure. ACE inhibition may also reduce angiotensin II-induced mesangial contraction and, thereby, increase the glomerular filtration surface. More controversy exists with regard to the intrarenal hemodynamic effects of $\mathrm{Ca}^{2+}$ antagonists. Although their ability to induce substantial afferent arteriolar vasodilatation is well demonstrated, their

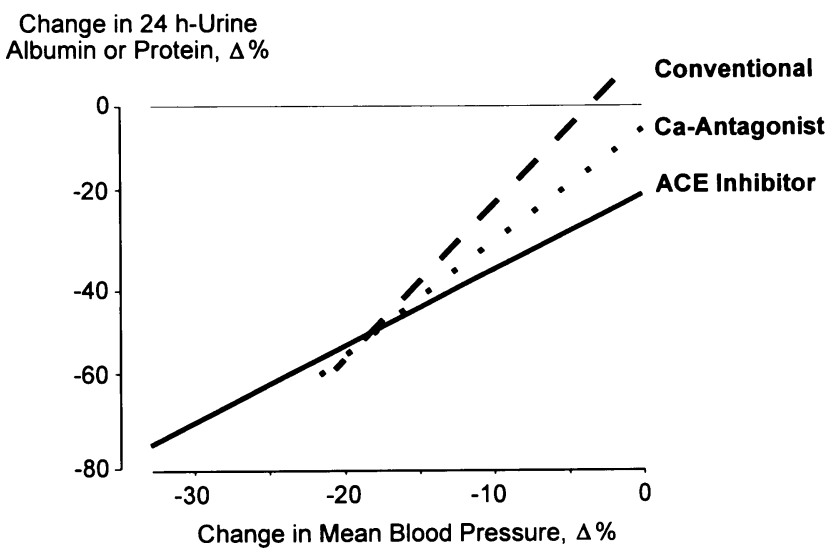

FIGURE 5. Percentage changes in albuminuria-proteinuria as related to blood pressure changes in diabetics on antihypertensive drugs. 
effect on efferent arteriolar resistance remains controversial. In animal and human studies verapamil and diltiazem have been noted to lower glomerular capillary pressure. ${ }^{19,73,74}$ The majority of studies investigating the renal hemodynamics of dihydropyridines showed no effect of nifedipine on efferent arteriolar resistance. ${ }^{75}$ Therefore, a beneficial influence of lowered systemic BP on glomerular pressure may be antagonized by preferential afferent over efferent glomerular vasodilatation, which occurs with certain $\mathrm{Ca}^{2+}$ antagonists. ${ }^{76}$

Considering nonhemodynamic actions, certain $\mathrm{Ca}^{2+}$ antagonists may tend to inhibit renal hypertrophy associated with diabetes. ${ }^{77}$ Both $\mathrm{Ca}^{2+}$ antagonists and ACE inhibitors may influence beneficially the metabolism of mesangial cells, ${ }^{77,78}$ whereas ACE inhibitors also may decrease glomerular permeability for proteins, ${ }^{25,79}$ probably by affecting charge and size selectivity of the glomerular capillary barrier in humans. ${ }^{80} \mathrm{ACE}$ inhibitors also limited the development of glomerular structural lesions as well as tubular interstitial damage. The biological mechanisms that could prevent these lesions are not completely understood, but studies in mesangial cells suggested the involvement of nitric oxide, ${ }^{81}$ which itself could be influenced by ACE inhibitors by inhibition of local bradykinin degradation. ${ }^{24,81}$ On the other hand, the lack of effect of nifedipine on albumin excretion may depend, perhaps in part, on proximal tubular interactions. ${ }^{46}$ Nifedipine caused a marked reduction in fractional lithium reabsorption and a corresponding increase in lithium clearance. ${ }^{82} \beta_{2}$-Microglobulin, a freely filterable protein and, therefore, also used as a marker of proximal tubular function, ${ }^{83}$ was significantly increased during nifedipine treatment compared with lisinopril therapy. ${ }^{46,84}$ The inhibitory effect of nifedipine on several proximal tubular function markers is consistent with the possibility that it might also inhibit proximal tubular albumin reabsorption, thereby promoting albuminuria despite its systemic antihypertensive effect.

As ACE inhibitors exert a specific antiproteinuric effect even without a change in systemic BP (Figure $5)$, they are superior to other agents in treating microalbuminuria or overt proteinuria in initially normotensive or mildly hypertensive diabetic patients. On the other hand, when systemic BP can be lowered by $20 \%$, as it is desirable and achievable in more severely hypertensive patients, $\mathrm{ACE}$ inhibitors, conventional therapy, and several $\mathrm{Ca}^{2+}$ antagonists all have a distinct antiproteinuric action.

Nevertheless, effects of agents on the kidney cannot be the sole criterion in selecting an antihypertensive drug for diabetic patients. The influence of drugs on serum lipid levels and glucose and potassium metabolism as well as their ability to reduce left ventric- ular hypertrophy should also be considered. ${ }^{27,85} \mathrm{Al}-$ though thiazide or loop diuretics and $\beta$-blockers can have an adverse metabolic influence, ACE inhibitors may improve slightly insulin resistance ${ }^{86}$ and, thereby, tend to improve glucose control in NIDDM patients. ${ }^{87} \mathrm{ACE}$ inhibitors and $\mathrm{Ca}^{2+}$ antagonsits also are neutral with regard to serum lipoproteins.

Most important, the ultimate goal of therapy is to improve life prognosis. In essential hypertension, BPlowering drug treatment based on diuretics in high dosage satisfactorily reduced cerebrovascular but not coronary complications or sudden death. ${ }^{88}$ However, in diabetic patients a beneficial influence of conventional antihypertensive therapy on prognosis has not been demonstrated. In fact, based on retrospective analyses, different investigators noted an excess mortality of diuretic-treated diabetic patients. ${ }^{89,90}$ Evaluating the prognostic outcome in diabetic patients with severe retinopathy, Warram et $\mathrm{al}^{90}$ found a 3.8 times higher cardiovascular mortality rate in patients treated with diuretics alone than in diabetic patients with untreated hypertension; the cardiovascular mortality rate was increased in diuretic-treated diabetic subjects with or without clinical proteinuria. On the other hand, it was calculated that in the very highrisk group of patients with diabetic nephropathy, effective BP control might possibly reduce 10 -year mortality rates from 65 to $20 \% .{ }^{91}$ In the first large prospective trial on prognosis, long-term ACE inhibition with captopril in overt diabetic nephropathy has just been reported to reduce markedly their combined risk of mortality or needing dialysis or transplantation. ${ }^{92}$ These data underline the achievable long-term benefits of effective drug treatment on the prognosis in a special high-risk group of patients.

Based on the available data, ACE inhibitors have emerged as the preferred first-line drugs in the treatment of diabetic patients with nephropathy. Furthermore, ACE inhibitors, $\mathrm{Ca}^{2+}$ antagonists other than nifedipine and, if necessary, the diuretic indapamide are effective antihypertensive drugs that do not affect adversely metabolic profile of diabetic patients. ${ }^{86}$

\section{REFERENCES}

1. United States Renal Data System: USRDS 1990 Annual Data Report. Bethesda, MD, The National Institutes of Health, National Institutes of Diabetes and Digestive Diseases, 1990.

2. Centers for Disease Control: End-stage renal disease associated with diabetes. United States 1988. MMWR 1989;38:546-548.

3. Viberti GC: Microalbuminuria as a predictor of clinical nephropathy in insulin dependent diabetes mellitus. Lancet 1982;i:1430-1432.

4. Mattock MB, Morrish NJ, Viberti GC, et al: Prospective study of microalbuminuria as predictor of mortality in NIDDM. Diabetes 1992;41:736-741. 
5. Mogensen $\mathrm{CE}$, Hansen KW: Preventing and postponing renal disease in insulin-dependent diabetes by glycemic and nonglycemic intervention. Contrib Nephrol 1990;78:73-100.

6. Krolewsky AS, Warram JH, Christlieb AR, et al: The changing natural history of nephropathy in type I diabetes. Am J Med 1985;78:785-794.

7. Parving $\mathrm{HH}$, Hommel E: Prognosis in diabetic nephropathy. Br Med J 1989;299:230-233.

8. Viberti GC, Yip-Messent J, Morocutti A: Diabetic nephropathy. Diabetes Care 1992;15:1216-1225.

9. Deckert T, Feldt-Rasmussen B, Borch-Johnsen K, et al: Natural history of diabetic complications: early detection and progression. Diabetic Med 1991;8(Symposium):S33-S37.

10. Hasslacher C, Wolfrum M, Stech G, et al: Diabetische Nephropathie bei Typ-II-Diabetes. Dtsch Med Wschr 1987;112:1445-1449.

11. Nelson RG, Pettitt DJ, Baird HR, et al: Pre-diabetic blood pressure predicts urinary albumin excretion after the onset of type 2 (non-insulin-dependent) diabetes mellitus in Pima Indians. Diabetologia 1993;36:9981001.

12. Morrish NJ, Stevens LK, Head J, et al: A prospective study on mortality among middle-aged diabetic patients (the London cohort of the WHO Multinational Study of Vascular Disease in Diabetics). II: associated risk factors. Diabetologia 1990;33:542-548.

13. Wilson PW, Cupples LA, Kannel WB: Is hyperglycemia associated with cardiovascular disease? The Framingham Study. Am Heart J 1991;121(2 Pt 1):586590.

14. Borch-Johnsen K, Kreiner S: Proteinuria: value as a predictor of cardiovascular mortality in insulin dependent diabetes mellitus. Br Med J 1987;294:1651-1654.

15. Zeller K, Whittaker E, Sullivan L, et al: Effect of restricting dietary protein on the progression of renal failure in patients with insulin/dependent diabetes mellitus. N Engl J Med 1991;324:78-83.

16. Christiansen CK, Mogensen CE: Effect of antihypertensive treatment on progression of incipient diabetic nephropathy. Hypertension 1985;7(suppl 2):109-113.

17. Parving $\mathrm{HH}$, Andersen AR, Smidt UM, et al: Effects of antihypertensive treatment on kidney function in diabetic nephropathy. Br Med J 1987;294:1443-1447.

18. Parving HH, Hommel E, Smidt UM: Protection of kidney function and decrease in albuminuria by captopril in insulin dependent diabetics with nephropathy. $\mathrm{Br}$ Med J 1988;297:1086-1091.

19. Bakris GL, Barnhill BW, Sadler R: Treatment of arterial hypertension in diabetic humans: importance of therapeutic selection. Kidney Int 1992;41:912-919.

20. Björck $S$, Mulec $H$, Johnsen SA, et al: Renal protective effect of enalapril in diabetic nephropathy. Br Med J 1992;304:339-343.

21. Walker WG, Hermann J, Yin D, et al: Diuretics accelerate diabetic nephropathy in hypertensive insulindependent and non-insulin-dependent subjects. Trans Assoc Phys 1987;100P:305-315.

22. Anderson S: Renal hemodynamics of calcium antago- nists in rats with reduced renal mass. Hypertension 1991;17:288-295.

23. Epstein M: Calcium antagonists and the kidney: implications for renal protection. Kidney Int 1992; 41(suppl 36):S66-S72.

24. Johnston CT, Clappison BH, Anderson WP, Yasujima M: Effect of angiotensin-converting enzyme inhibition on circulating and local kinin levels. Am J Cardiol 1982;49:1401-1404.

25. Remuzzi A, Puntorieri S, Battaglia C, et al: Angiotensin converting enzyme inhibition ameliorates glomerular filtration of macromolecules and water and lessens glomerular injury in the rat. J Clin Invest 1990;85: 541-549.

26. Björck S, Mulec H, Johnsen SA, et al: Contrasting effects of enalapril and metoprolol on proteinuria in diabetic nephropathy. Br Med J 1990;300:904-907.

27. Weidmann P, Boehlen LM, de Courten M, Ferrari P: Antihypertensive therapy in diabetic patients. J Human Hypertens 1992;6(suppl 2):S23-S36.

28. Weidmann P, Böhlen LM, de Courten M, Ferrari P: Effects of different antihypertensive drugs on human diabetic proteinuria. Nephrol Dial Transplant 1993;8: 582-584.

29. SAS Institute Inc: SAS User's Guide: Statistics, Version 5. Cary, NC, SAS Institute, 1985.

30. Kleinbaum DG, Kupper LL, Muller KE: Applied Regression Analysis and Other Multivariable Methods, Chapter 14. Belmont, CA, Wadsworth Publishing, 1988.

31. Björck S, Nyberg G, Mulec $\mathrm{H}$, et al: Beneficial efffects of angiotensin converting enzyme inhibition on renal function in patients with diabetic nephropathy. Br Med J 1986;293:471-474.

32. D'Angelo A, Sartori L, Gambaro G, et al: Captopril in the treatment of hypertension in type I and type II diabetic patients. Postgrad Med J 1986; 62(suppl 1):6972 .

33. Zanella MT, Salgado BJL, Kohlmann O, Ribeiro AB: Converting enzyme inhibition: a therapeutical option for diabetic patients. Hypertension 1987;9:543.

34. Casado S, Carrasco MA, Arrieta FJ, Herrera JL: Effects of captopril in diabetic patients with different degrees of blood pressure and proteinuria. Postgrad Med J 1988;64(suppl 3):85.

35. Romero R, Sanmartí A, Salinas I, et al: Utilidad de los inhibidores de la enzima converiva de la angiotensina en el tratamiento de la nefropatìa diabetica. Med Clin (Barcelona) 1988;90:494-496.

36. Valvo E, Bedogna P, Casagrande P, et al: Effects of captopril on systemic and renal haemodynamics in patients with diabetic nephropathy and renal insufficiency. Postgrad Med J 1988;64(suppl 3):89.

37. Doyle AE, Alford ME, Cooper M, et al: A comparison of the effects of blood pressure reduction with perindopril and nifedipine on micro-albuminuria in hypertensive and normotensive diabetics. J Hypertens 1989;7(suppl 6):S361.

38. Stornello M, Valvo EV, Scapellato L: Hemodynamic, renal, and humoral effects of the calcium entry blocker 
micardipine and converting enzyme inhibitor captopril in hypertensive type II diabetic patients with nephropathy. J Cardiovasc Pharmacol 1989;14:851-855.

39. Morelli E, Loon N, Meyer T, et al: Effects of converting-enzyme inhibition on barrier function in diabetic glomerulopathy. Diabetes 1990;39:76-82.

40. Nieto J, Sanchez M, Lozano L, et al: Hypertension and proteinuria in diabetic patients. Long-term effect of captopril. Kidney Int 1990;37:1609-1610.

41. Slomowitz LA, Bergamo R, Grosvenor M, Kopple JD: Enalapril reduces albumin excretion in diabetic patients with low levels of microalbuminuria. Am J Nephrol 1990;10:457-462.

42. Apperloo AJ, de Zeeuw D, Sluiter HE, de Jong PE: Differential effects of enalapril and atenolol on proteinuria and renal haemodynamics in non-diabetic renal disease. Br Med J 1991;303:821-824.

43. Bochicchio T, Ron O, Sandoval G, et al: Effect of captopril on proteinuria and renal hemodynamics in hypertensive type-II diabetic patients with nephropathy. Hypertension 1991;17:422.

44. Brusztyn M, Kobrin I, Fidel J, Ben-Ishay D: Improved kidney function with cilazapril in hypertensive type II diabetics with chronic renal failure. J Cardiovasc Pharmacol 1991;18:337-341.

45. Haisa S, Norii T, Takatori E, et al: Effects of angiotensin-converting enzyme inhibitor (alacepril) and calcium antagonist (nicardipine) in hypertensive noninsulin-dependent diabetic patients with microalbuminuria. J Diabetic Complications 1991;5:162-164.

46. Holdaas H, Hartmann A, Lien MG, et al: Contrasting effects of lisinopril and nifedipine on albuminuria and tubular transport functions in insulin dependent diabetes with nephropathy. J Int Med 1991;229:163-170.

47. Marre M, Hallab M, Billiard A, et al: Small doses of ramipril do reduce microalbuminuria in diabetic patients with incipient nephropathy independently of blood pressure changes. J Cardiovasc Pharmacol 1991;18(suppl):S165-S168.

48. Martello MA, Daccordi HA, Ferder LF, et al: Enalapril versus nifedipine in diabetic patients with hypertension and proteinuria (abst). Diabetes 1991;40:506A.

49. Mathiesen ER, Hommel E, Giese J, Parving HH: Efficacy of captopril in postponing nephropathy in normotensive insulin dependent diabetic patients with microalbuminuria. Br Med J 1991;303:81-87.

50. Silvani G, Bondi A, Nizzoli M, et al: Enalapril versus low protein diet: effects on microalbuminuria and kidney function in normotensive type I (insulindependent) diabetic patients with incipient nephropathy (abst). Diabetes 1991;40(suppl 1):441A.

51. Bochicchio T, Ron O, Sandoval G, et al: Antiproteinuric effect of captopril is associated with restoration of renal functional reserve (RFR) in NIDDM patients with nephropathy. J Hypertens 1992;10(suppl 4):S134.

52. Fioretto P, Frigato F, Velussi M, et al: Effects of angiotensin converting enzyme inhibitors and calcium antagonists on atrial natriuretic peptide release and action on albumin excretion rate in hypertensive insulin-dependent diabetic patients. Am J Hypertens 1992; 5:837-846.
53. Jungmann E, Haak T, Malanyn M, et al: Comparative study on renal effects of nitrendipine vs. enalapril in microalbuminuric patients with type 1 diabetes mellitus. J Hypertens 1992;10(suppl 4):S242.

54. Milagres R, Kohlmann O, Zanella MT, Ribeiro AB: Cilazapril reduces proteinuria in insulin dependent diabetes mellitus (IDDM) without change in renal hemodynamics. J Hypertens 1992;10(suppl 4):S276.

55. Romero $R$, Salinas I, Lucas A, et al: Comparative effects of captopril versus nifedipine on proteinuria and renal function. Diab Res Clin Pract 1992;17:191-198.

56. Romero R, Salinas I, Borràs $M$, et al: Effects of angiotensin converting enzyme inhibitors in normotensive type 2 diabetic patients with microalbuminuria: a randomised study with control group. J Hypertens 1992;10(suppl 4):S109.

57. Tettamanti F, Zoppi A, Malmani GD, et al: Effects of ramipril and nitrendipine on proteinuria in hypertensive patients with albuminuric NIDDM. J Hypertens 1992;10(suppl 4):S102.

58. Hallab M, Gallois Y, Chatellier G, et al: Comparison of the effect of reduction in microalbuminuria by enalapril and hydrochlorothiazide in normotensive patients with insulin dependent diabetes. Br Med J 1993;306: 175-192.

59. Lacourciere Y, Nadeau A, Poirier L, Tancrède G: Captopril or conventional therapy in hypertensive type II diabetics. Hypertension 1993;21:786-794.

60. O'Donnell MJ, Rowe BR, Lawson N, et al: Comparison of the effect of an angiotensin converting enzyme inhibitor and a calcium antagonist in hypertensive, macroproteinuric diabetic patients: a randomised double-blind study. J Hum Hypertens 1993; 7:333-339.

61. O'Donnell MJ, Rowe BR, Lawson N, et al: Placebocontrolled trial of lisinopril in normotensive diabetic patients with incipient nephropathy. J Hum Hypertens 1993;7:327-332.

62. Ravid M, Savin H, Jutrin I, et al: Long-term stabilizing effect of angiotensin-converting enzyme inhibition on plasma creatinine and on proteinuria in normotensive type II diabetic patients. Ann Int Med 1993;118:577581.

63. Slataper R, Vichnair N, Sadler R, Bakris GL: Comparative effects of different antihypertensive treatments on progression of diabetic renal disease. Arch Int Med 1993;153:973-980.

64. Bianchi S, Bigazzi R, Baldari G, Campese VM: Microalbuminuria in patients with essential hypertension. Am J Hypertens 1991;4:291-296.

65. Christensen CK, Mogensen CE: Antihypertensive treatment: long-term reversal of progression of albuminuria in incipient diabetic nephropathy. J Diabetic Complications 1987;1:45-52.

66. Janka HU, Weitz T, Blümner E, et al: Hypertension and micro-albuminuria in diabetic patients taking indapamide. J Hypertens 1989;7(suppl 6):S316-S317.

67. Gambardella S, Frontoni S, Felici MG, et al: Efficacy of antihypertensive treatment with indapamide in patients with noninsulin-dependent diabetes and persistent microalbuminuria. Am J Cardiol 1990;65:46H$50 \mathrm{H}$. 
68. Tindall $\mathrm{H}$, Urquhart $\mathrm{S}$, Stickland $\mathrm{M}$, Davies JA: Treatment with atenolol prevents progression of microalbuminuria in type I diabetic patients. Curr Med Res Opin 1991;12:516-520.

69. Bauer JH, Reams GP, Hewett J, et al: A randomized, double-blind, placebo-controlled trial to evaluate the effect of enalapril in patients with clinical diabetic nephropathy. Am J Kidney Dis 1992;20:443-457.

70. Mimran A, Insua A, Ribstein J, et al: Comparative effect of captopril and nifedipine in normotensive patients with incipient diabetic nephropathy. Diabetes Care 1988; 11:850-853.

71. Zusman RM: Renin and non-renin-mediated antihypertensive actions of converting enzyme inhibitors. Kidney Int 1984;25:969-978.

72. Keane WF, Anderson S, Aurell M, et al: Angiotensin converting enzyme inhibitors and progressive renal insufficiency. Ann Int Med 1989;111:503-516.

73. Demarie BK, Bakris GL: Effects of different calcium antagonists on proteinuria associated with diabetes mellitus. Ann Int Med 1990;113:987-988.

74. Anderson S: Renal hemodynamics of calcium antagonists in rats with reduced renal mass. Hypertension 1991;17:288-295.

75. Valentino VA, Wilson MD, Weart W, Bakris GL: A perspective on converting enzyme inhibitors and calcium antagonists in diabetic renal disease. Arch Intern Med 1991;151:2367-2372.

76. Loutzenhiser R, Epstein M: Renal microvascular actions of calcium antagonists. J Am Soc Nephrol 1990; 41:487S-493S.

77. Bakris GL: Renal effects of calcium antagonists in diabetes mellitus. Am J Hypertens 1991;4:487S-493S.

78. Epstein M: Calcium antagonists and the kidney: implications for renal protection. Kidney Int 1992; 41(suppl 36):S66-S72.

79. Meyer TW, Morelli E, Loon N, et al: Converting enzyme inhibition and glomerular size selectivity in diabetic nephropathy. J Am Soc Nephrol 1990;1(suppl 2):564-568.

80. Ritz E, Orth S, Weinreich T, Wagner J: Systemic hypertension versus intraglomerular hypertension in progression. Kidney Int 1994;45:438-442.

81. Shultz PJ, Schorrer HE, Raij L: Effects of endotheliumderived relaxing factor and nitric oxide on rat mesangial cells. Am J Physiol 1990;258:F162-F167.
82. Koomans HA, Boer WH, Mees EJD: Evaluation of lithium clearance as a marker of proximal tubule sodium handling. Kidney Int 1989;36:2-12.

83. Schardijn GHC, van Eps LWS: Beta-2-microglobulin: its significance in the evaluation of renal function. Kidney Int 1987;32:635-641.

84. Christensen CK, Lederballe Pederssen O, Mikkelsen E: Renal effects of acute calcium blockade with nifedipine in hypertensive patients receiving betaadrenergic-blocking drugs. Clin Pharmacol Ther 1982. 32:572-576.

85. Böhlen LM, Weidmann P, de Courten M, et al: Antihypertensive drug effects on left ventricular hypertrophy: meta-analysis considering duration of treatment. Abstract of the 15th Scientific Meeting of the International Society of Hypertension, Melbourne, March 1994.

86. Weidmann P, Boehlen LM, de Courten M: Pathogenesis and treatment of hypertension associated with diabetes mellitus. Am Heart J 1993;125:1498-1513.

87. Bergemann R, Betzin J, Nawrath T, Weidmann P: Verbesserte Glukoseeinstellung und Albuminurie bei Diabetikaern unter ACE-Hemmer-Behandlung: Eine Metaanalyse publizierter Studein aus den Jahren 1985 bis 1990. Schweiz Med Wochenschr 1993;122:1369 1376.

88. Collins R, Peto R, MacMahon S, et al: Blood pressure, stroke and coronary heart disease. Part 2: short-term reduction in blood pressure: overview of randomized drug trials in their epidemiological context. Lancet 1990;i:827-838.

89. Klein R, Moss SE, Klein BEK, DeMets DL: Relation of ocular and systemic factors to survival in diabetes. Arch Intern Med 1989;149:266-272.

90. Warram JH, Laffel LMB, Valsania P, et al: Excess mortality associated with diuretic therapy in diabetes mellitus. Arch Intern Med 1991;151:1350-1356.

91. Parving $\mathrm{HH}$ : The impact of hypertension and antihypertensive treatment on the course and prognosis of diabetic nephropathy. J Hypertens 1990;8(suppl 7):S187-S191.

92. Lewis EJ, Hunsicker LG, Bain RP, Rohde RD: The effect of angiotensin-converting-enzyme inhibition on diabetic nephropathy. N Engl J Med 1993;329:14561462. 